their work in the university: Mr. G. P. Duffy (department of neurosurgery), Dr. D. W. Young (department of medicine), Dr. A. R. H. Hastie (division of pathological studies), Dr. E. C. Fox (department of dental health)

The title of assistant clinical tutor has been conferred on the following senior registrars (anaesthetics) for the period of their service with the United Birmingham Hospitals: Dr. J. D. Anderson, Dr. Minakshi Biswas, Dr. Jennifer D. Burton, Dr. B. C. Jones.

Appointments.-Dr. T. A. Betts (lecturer, department of psychiatry); Dr. Valerie Gracey (part-
time research fellow, Institute of Child Health); Mr. time research fellow, Institute of Child Health); $\mathrm{Mr}$. P. M. Lea (lecturer, department of anatomy); Dr. I. Myskova (part-time research fellow, department of human genetics); Dr. C. W. Taylor (part-tim

At a Congregation on 12 December the following degrees were conferred

M.D.-1Barbara M. Ansell, 1*E. A. Jones, E. L. Jones, D. C. Dukes, J. C. Gunn, ${ }^{*} \mathrm{C}$. H. J. Swan. Hearn, J. A. Kiernan, K. M. Spyer, J. B. Whitfield, *J. F. Perez-Gonzalez.

M.B., CH.B.-J. Calvert, I. B. Chait, D. I.
Dowson, D. W. Higginson, S. mond.

The following degrees were conferred in $a b$ sentia on students in the University College of Rhodesia by special warrant on 1 Decembe 1969 M.B., CH.B.-123tG. O. R. Holmgren, G. H.
Adam, N. H. D. Atherstone, B. A. Bramston,
5J. W. De Bene, A. J. Hammer, M. Jelbert, 2A. S. Latif, M. Lock, 2A. M. McKeag, H. J. Moffat, D. E. Monks, Juleiga Moosa, K P. K Runyowa, 2D. M. Sanders, Patricia Whitlow.

1 With honours.

3 Distinction in paediatrics.

Distinction in surgery.

5 Distinction in social medicine.

* In absentia.

\section{ROYAL COLLEGES OF PHYSICIANS OF THE UNITED KINGDOM}

At a meeting of the Royal College of Physicians of London held on 29 January, at a meeting of the Royal College of Physicians of Edinburgh held on 3 February, and at a meeting of the Royal College of Physicians and Surgeon of Glasgow held on 2 February the following were elected Members of the Royal Colleges of Physicians of the United Kingdom:

M. N. Abu Kamil, J. H. Addy, M. W. Adler, G. R. Ah-Moye, G. D. Ananda, A. Y. Amin-Addo, R. Arnold, P. J. August, R. R. Bailey, D. Ballantyne, D. L. Barnard, D. M. J. Barry, N. G. Basavaraju, A. Basten, M. Behan, I. V. Benn, E. D. Ben-
nett, P. R. Betts, P. L. A. Bill, R. H. Briant, J. P. I nett, P. R. Betts, P. L. A. Bill, R. H. Briant, J. P. I
Bridge, J. M. Bridson, R. C. Brown, N. K. Burki,
P. K. Buxton, Anne v. Camp, R. Canepa-Anson, P. K. Buxton, Anne V. Camp, R. Canepa-Anson, F. G. F. Chin, G. S. H. Chung, J. H. Cummings, Deutsch, R. A. J. Eady, D. W. Eccleston, G. P En-Nimri, E. M. Eronini, D. J. Exing, Adel A Fram, I. W. Fawcett, P. S. L. Fernando, O. S Garde, A. D. N. Gelson, N. R. Ghosh, B. M. Goodge, J. R. Govan, B. Gribbin, M. A. Hai, D. R Hall, B. D. W. Harrison, R. C. Heading, Belle $M$. Hedge, Vanessa J. Hester, R. C. Hilton, R. A. C
Hughes, R. K. Jacoby, M. H. Jafary, P. D. James, M. V. Jeeva Raj, Amina Jindani, D. I. Johnston,
P. M. L. Jones, Vasantha K. K. Kamath, M. F. P. M. L. Jones, Vasantha K. K. Kamath, M. F. P. A. King Lewis, Parveen J. Kumar, Christine J. S. P. A. King Lewis, Parveen J. Kumar, Christine J. S. Sunil P. Liyanage, M. F. J. Lowry, S. A. Maar, v. McLellan, W. J. W. Mallinson, A. W. Matthews, Madeline D. Mayne, J. E. Meyer, Cicely J. Millbank, H. C. Miller, M. Mishra, H. N. Misra, P. F. Marigowda Nagaraju, E. S. Newlands, G. D. Ohlrich, R. E. Oliver, M. I. A. Omer, O. I. I.
Osman, A. I. Pack, R. L. Page, H. M. Palmer, Soumitri Panigrahi, Hiranmay Paul, Sumana M. Perera, D. G. C. Presbury, J. Pritchard, A. Qayum, H. Quadir, Phimol Rajjayabun, Leila Raju, ShaR. P. A. Rivers, Margaret H. Rose, M. Richardson, Sadler, Mary C. Sanderson, N. Saravanapavananthan, Annapurniah S. Shankor, A. D. Sharma, R. N. Silverman, P. D. Snashall, Narendra K. Sood, Margaret E. Sprackling, S. A. Srivongse, A. P. Staz, D. R. Triger, T. W. Turner, C. P. Vartan, T. L. W. R. G. Wartal Walker, D. W. Ward, J. P. Warren, Whelton, R. D. Whitla, J. C. Wilson, W. J. Windebank, Angela M. Wood, M. Yunus, A. Bux, H. P. Garg, Usha Jayaswal, M. A. Quader, A. B. M. S. Visvanathan.

ROYAL COLLEGE OF SURGEONS OF EDINBURGH

At a meeting of the College held on 6 February, with Mr. J. R. Cameron, president, in the chair, the following were admitted as Fellows :

Ila S. Mody, M. C. Pauwaa, R. D. Ponniah, R. W.
Sillar, N. Subramaniam, C. E. W/allace, J. R. Waatson.

ROYAL COLLEGE OF OBSTETRICIANS AND GYNAECOLOGISTS

At meetings of the Council of the College held on 30 and 31 January the following award and elections were made:

EARdLey Holland Gold Medal fOR 1970.Professor Ian Donald.

Mrs. Margaret Black.

The following were elected to the Membership without examination and immediately to the Fellowship:

Zubaida Aziz, E. De Valera, A. K. Naim

The following were elected to the Fellowship ad eundem under by-law 10a:

C. Astley Clarke, F. E. Hytten, Margaret Jackson Asteman Sundberg.

The following were elected to the Fellowship: Farid Akasheh, M. P. Awon, A. L. Baccarini, Sreemanta K. Banerjea, Renukana Banerjee, S. L. Barron, M. K. Basu Mallick, N. A. Beischer,
K. K. O. Bentsi-Enchill, Catherine I. Blyth, Florence J. G. Chouler, H. J. H. Claassens, S. B. Cooper J. J. De Wet, C. Douglas-Smith, Sunit K. Dutt, A. A Earn, P. M. Elliott, A. D. El-Tannir, L. A. J. Guadex, J. W. S. Harris, D. F. Hawkins, P. E. Jeffery, A. G. Jones, J. Joseph, Pullat Kalyanikutty R. A. Kenihan, B. L. G. Kneale, D. J. Lancaster, K. B. Layton, W. Lees, G. C. Liggins, J. D. M. C. Michelow, A. K. Mitra, B. J. Murphy, R. N.
N. Machonald Nag, U. N. Pathak, Clare Phillips, B. G. Pickles, Robertson, M. Robinson, Heather J. S. Ross, J. P. Roux, J. M. Samson, N. H. W. Saxby, Diaa SeifStewart, J. St. George, T. J. S. R. Train, Yin-K Tsao, F. L. A. Vernon, J. N. Ward, D. W. Warrell.

The following were admitted to the Membership

Usama Abdulla, Adeeba Abdulnour, E. A. Abrok Zahida, Ahmad, Razia Ahmed, M. S. Akhter, P. S Allen, G. A. C. B. Anteson, Amathul Azeez, BalBikash C. Basu, I. J. Batwala, H. D. Bauer, Lutfun N. Begum, F. R. Bellingham,* Phoonoo P. Bezboruah, Kailash Bhalla, Elsje G. M. Boes, W. P Bradford, A. P. Briggs, D. S. Browne, J. E. F Bruce, R. M. Buckley, D. C. MacD. Burns, Mildred J. Butterworth, Bulbul Chakrabarti, Yew F. Chan C. Chandrakar, A. M. Z. Chang, Manashi Chatterjee, Swee Fah Cheah, M. Chi Eng Cheng, A. D. Clark P. B. B. Clarke, P. Condos, Vanni Cremona, S. N R. W. Duncan, Zahida K. Durrani, A. G. B. Dutton, P. J. Edelman, R. P. Edwards, Gabriel O. Ghandour, G. L. D. Gibbens, P. R. Frank, O. S Griffiths, A. A. H. Gunaratne, Claude-A!bert Hakim D. Hangchi, Kathieen S. Haworth, D. F. G. Hayes, R. B. Hutcheson, E. U. Ibiam, P. N. Jennings, S. B Johnson, D. N. Joyce, R. A. A. Kasrawi, Moiro B Kelly, A. M. Khan, I. U. Khan, S. S. Khunda. D. Kong Lee, T. W. H. Lim, C. B. R. Lunan, Marjor G. McK. McKinnon, Berna J. Madil, Vettivelu May,* S. Mehta, .J. S. de v. Metters, Kam-Hung, P. Mok, D. M. Mooney, M. P. Neary, Z. Niaz P. J. Nugent, P. C. Nweke, P. F. M. O'Connor, A. E
Owen, P. M. O. Oyolu, S. Y. Pan, K. J. Parikh
P. T. Patten, C. Pavlou, M. E. Pawson, Audrey $M$ Glatt, W. P. Porter, M. S. Rahman, S. Rana, C. Ray, M. L. Saha, G. F. Salib, Nirmala M. Sanghvi, Shardlow, G. R. J. Sheehan, K. Soofi, B. R. Spurrett, A. M. Tayeh, D. S. Taylor, S. E. Tchamouroff, Gloria G. C. Teoh, D. J. Thomas, N. R. A. Trickey, A. J. Tyack, C. J. Van Gelderen A. C. R. G. Wass, J. H. Wee, C. J. Wheatley, *Awarded regional Councils' Gold Medals.

\section{Corrections}

\section{L-Dopa}

In the article on "Treatment of Parkinsonism with Laevo-Dopa" (7 February, p. 331), the second sentence of the summary should read "Nine were markedly and 13 moderately improved, and, of these, 11 patients continued to take the drug." These figures quoted in the first sentence of the second paragraph of the section on "Moderate Improvement" should also read " 13 " and " 11 ," respecively. Cyclizine 50 mg. was administered three times daily.

\section{G.P.s and the District Hospital}

We regret that the letter on this subject from Dr. H. W. Fladée (14 February, p. 436) was printed under the wrong heading.

\section{Notice to Authors}

When original articles and letters for publication are not submitted exclusively to the British Medical fournal this must be stated.

Correspondence on editorial business should be addressed to the Editor, British Medical fournal, B.M.A. House, Tavistock Square, London W.C.1. Telephone: 01-387 4499. Telegrams: Aitiology, London W.C.I.

Authors wanting reprints of their articles should notify the Publishing Manager, B.M.A House, Tavistock Square, W.C.1, on receipt of proofs.

\section{Subscriptions}

Members' subscriptions should be sent to the Secretary of the British Medical Association B.M.A. House, London, or to the Scottish Secretary, B.M.A. Scottish Office, Drumsheugh Gardens, Edinburgh.

Doctors who are not members of the B.M.A can subscribe to the B.M.F. The rates for doctors resident in the United Kingdom and abroad are given on the first page of the classified advertisements. These include the rate fo the North American “Air Express," which is available to both members and non-members of the B.M.A.

\section{Classified Advertisements}

Doctors Abroad.-Copies of the appointmen vacancies advertised in the B.M.f. can be sen by airmail on request. Members' rate: the minimum cost is 40 s. for six weeks' supply, for which copies of vacancies in up to five section of the classified advertisements will be sent. Non-members' rate $60 \mathrm{~s}$. minimum for sir wecks' supply of five headings or less. Additional headings (for members and nonmembers) 10s. each for six weeks' supply. Orders for specific grades in any section canno be accepted. Payment must be prepaid and enclosed with the application.

Details of rates, etc., for classified advertisements appear on the first page of the classified section. 